Article

\title{
Decoupling Economic Development from the Consumption of Finite Resources Using Circular Economy. A Model for Developing Countries
}

\author{
Carlos Scheel *, Eduardo Aguiñaga $₫$ and Bernardo Bello \\ EGADE Business School, Tecnologico de Monterrey, Monterrey 64849, Mexico; eduardo.aguinaga@tec.mx (E.A.); \\ bernardo.bello.92@gmail.com (B.B.) \\ * Correspondence: cscheel@tec.mx
}

Received: 31 December 2019; Accepted: 27 January 2020; Published: 11 February 2020

check for updates

\begin{abstract}
Sustainable development is a major concern for developing and developed economies as economic growth has to led to scarcer and more expensive resources. Although countries have established public policies focusing on resource and energy efficiency, there is an increasing need for a coordinated industrial strategy able to create sustainable wealth through a holistic management of natural resources, capable of "decoupling" economic growth from resource extraction and natural deterioration. Consequently, the objective of the present research is to develop a decoupling model able to create increasing economic returns, reducing the social gap and regenerating the natural capital for regions in developing countries. Departing from a literature review on peer reviewed articles on successful industrial cases of decoupling around the world, we contrasted the linear production model with the United Nations Environment Program (UNEP)'s current four decoupling indicators in order to propose a more robust model. The result was an eight-factor decoupling model that used a well-supported framework for sustainable wealth creation named "circular value ecosystem" (CVES). By using system dynamics, we deployed the proposed framework using system dynamics modeling in order to improve the understanding of our proposal. We found that this model, with the proper regional conditions in developing countries, can: (1) reduce, through substitution, the consumption of natural resources; (2) produce alternative economic increasing returns; (3) reduce the negative environmental impacts; and (4) create self-sustainable wealth for the economy, the environment, and the social development of most stakeholders of these regions. Decoupling economic growth represents a complex and challenging task whose successful implementation can only be achieved if managed at a regional level with a systemic approach.
\end{abstract}

Keywords: economic decoupling; circular economy; circular value systems; sustainable wealth creation; system dynamics modeling; developing countries

\section{Introduction}

Although steady economic growth is one of the main objectives featured in the industrial policies of most developed countries, most of their economic activities are associated with the extraction and industrialization of natural resources. Such resources are becoming scarcer and more expensive to extract, leading to a decrease in resource efficiency and extensive environmental damage, particularly in developing countries [1].

Several studies concerned with sustainable development (e.g., [2,3]) have pointed out that regional policies and coordinated industrial strategies are required to develop a holistic management of natural resources, capable of "decoupling" economic growth from: (a) an excessive natural resource exploitation, (b) the extensive volumes of waste and residues produced by industrialization, (c) the negative 
environmental impacts, and, as a consequence, (d) a widening of the socioeconomic gap-circumstances that developing countries have suffered for decades, in contrast with industrialized ones.

Decoupling economic growth from resource extraction has encouraged research interest among scholars and authorities around the world since, among other things, the call from the United Nations Environment Program (UNEP)'s International Resource Panel to decouple human well-being from resource consumption [4]. Decoupling, itself, has become a nascent research field with its own decoupling theory [5] and numerous and increasing research papers on the subject (e.g., [6]). Ranging from analysis of decoupling at a micro level of analysis (e.g., [7,8]), to more regional macro level assessments (e.g., $[9,10])$, these studies acknowledge that decoupling is a complex systems challenge worth studying if true sustainability is to be attained in the face of a growing demand for resources by an increasing population [11]; the latter being one of the main reasons why effective decoupling mechanisms are needed.

However, after the recent industrial revolution produced by digital technologies, the emergence of a new era based on environmental technologies suggests that natural resource productivity (RP) is the core characteristic that must be optimized when implementing new sustainable strategies. In parallel development, resource efficiency (RE) is becoming a relevant factor for the formulation of sustainable policies of countries as well as the current planned expansion of resilient cities [12]. However, to increase RE requires enormous amounts of economic capital and restrictive public policies [3,13].

Figure 1 depicts the relationships between economic growth results of conventional industrialization, human well-being, resource use, and environmental impact. Environmental impacts and resource use may be controlled by an economic degrowth. However, this method is not a viable option for less-developed countries, where social and environmental issues are not a priority for their decision makers.

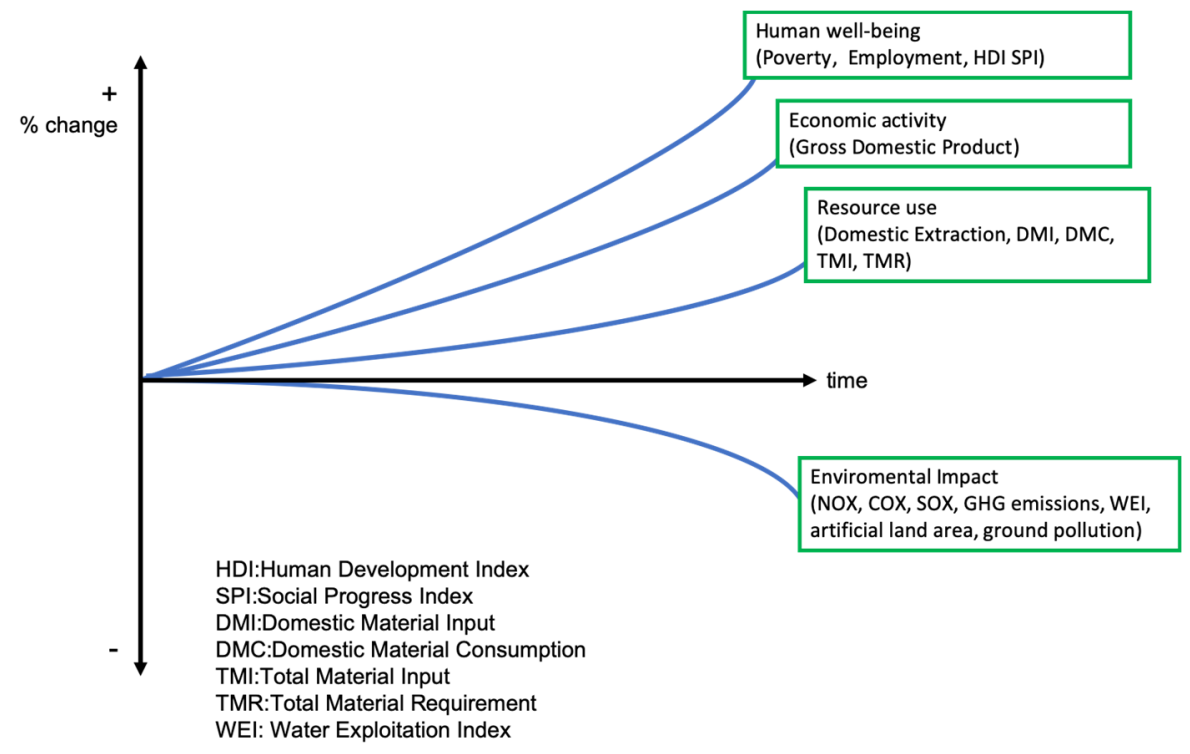

Figure 1. United Nations Environment Program (UNEP) representation of the relationship of four indicators regarding economic growth and environmental impact. Prepared by the authors based on the original graph by the UNEP [4].

Despite that the world is already full of waste and residues, the demand for raw materials is increasing globally $[14,15]$. Approximately $80 \%$ of consumer goods and materials are thrown away; more than $30 \%$ of processed foods go to waste once they enter the food supply chain. In Europe alone, the average occupancy of cars is less than $10 \%$, and from $10 \%$ to $15 \%$ of materials go to waste during construction. Additionally, over the next twenty years, the demand for raw materials will grow more than: $200 \%$ for farmland; $137 \%$ for water; $57 \%$ for steel; and we will need more than $32 \%$ of the current 
level of energy produced. On the other hand, there is an increasing demand for a new plastic economy capable of recycling at least $70 \%$ of the plastic produced, from its current low of $14 \%$ [16].

These data lead us to consider the decoupling of resources used to produce economic growth from environmental deterioration, as an essential activity. It is an issue that has reached the top economic development agencies [17], environmental protection organizations [4], government institutions [18] and several academic researchers (e.g., [3,19,20]).

The high demand for resources highlights that the focus on resource efficiency is only able to bring solutions to specific cases and within a short term, such as transportation logistics through fuel reduction; but in the long run, this solution would lead us to the deceleration of the economy [21,22]. Extant literature does not identify a proven model that provides a systemic approach capable to solve this decoupling issue effectively [23]. For sustainable development, in the long term, a model is needed in order to be adapted to several situations and regions—as the highly extractive economies-to work not only on optimizing efficiency factors or applying appropriate technologies for decoupling, but also seeking innovative mechanisms to create sustainable wealth based on alternative ways of producing new sources of economic value added [24].

Consequently, the following research questions arise, "Which innovative mechanisms can help the decoupling process beyond REs?" and "How will this mechanism be capable of decoupling economic growth for resource consumption?" We seek to answer these research questions by proposing a decoupling framework based on a systemic view of growth, and on a circular economy approach through the creation of a circular value ecosystem (CVES). Based on this framework, we contend that it is possible to create a viable circular value ecosystem capable of decoupling economic growth from natural resource extraction, through the transformation of residues, waste, and obsolete products into valuable assets, while simultaneously creating increasing economic returns, reducing the social gap and regenerating the natural capital for regions in developing countries.

The approach used in this paper focuses on the application of circular economy (CE) strategies $[25,26]$, with a systemic view of growth, and on the application of proper policies, i.e., innovation strategies to circularize towns and communities [27], adapted from successful cases, with lessons learned from countries that have been capable of decreasing the demand for natural resources and, at the same time, have created opportunities for sustainable growth by implementing non-usual business models.

Based on the sustainable wealth-creation approach by the innovation and enabling technologies (SWIT) framework [24], the present research proposes a model to assemble a "circular value ecosystem", which provides a cluster of industrial ecology synergies that have, simultaneously, a direct impact on the economic activity, the environmental regeneration, and on the social development of a region.

The SWIT framework has been applied in multiple industries and community cases. It is the result of several years of research and testing, and here, it has been adapted to develop a new systemic and effective approach for decoupling, focused on sustainable wealth creation.

\section{Literature Review}

Literature on decoupling is vast; however, the engagement of this phenomenon with a CE approach is less frequent. In contrast with authors [28], who found eleven articles, we discerned a limited increase of the research publications in this area after undertaking a content review of 32 articles addressing decoupling and a CE approach.

From these articles, we obtained a better understanding of the engagement of $\mathrm{CE}$ with the process of decoupling. Nine case studies, 11 quantitative research articles and 12 theory-building articles were found. In combination with public information, such as environmental reports, development reports, and other industrial cases, a summary is provided in the following subsections addressing the following: (1) the classification and measures of decoupling; (2) relevant research about decoupling; (3) the limits and obstacles of decoupling and (4) how CE has been engaged in the discussion of decoupling. 


\subsection{Classification and Measures of Decoupling}

Academic literature classifies decoupling as either relative or absolute. When the rate of resource use, or the environmental impact is less than the economic growth rate and positive, it is considered to be relative decoupling. Alternatively, when the relationship is zero or negative, it is called absolute decoupling $[29,30]$.

As shown in Figure 1, researchers account for economic growth with a unique index, the GDP; whereas the main procedure to account for material resources used in the economic activities is material flow analysis $[19,20]$. Furthermore, other indicators often used in empirical research encompass domestic extraction, domestic material input, domestic material consumption, total material input [28], and total material requirement [19] (see Figure 1 for definitions). To account for environmental impacts, researchers have used the life cycle assessment methodology [31] with indicators such as SOx, COx, NOx and greenhouse gases for air pollution (e.g., [29,32]); the water exploitation index, artificial land area and ground pollution [28] among others. Finally, the well-being variable in the equation, despite being a complex concept, has been addressed through indicators such as the poverty rate, the employment rate, the human development index and the social progress index [33].

Portraying the relationship of the concepts mentioned above, Figure 1 shows explicitly the problem of decoupling which can be summarized as: how to produce a sustainable economic growth while diminishing the use of resources and simultaneously creating positive environmental impacts on the region.

\subsection{Relevant Decoupling Cases}

Empirical literature about decoupling and city official reports have found that absolute and relative decoupling has occurred in countries like China [30], Finland [5], Germany [34], Denmark, Japan, and the United Kingdom [21,28]. It can be observed that in some countries, active participation of the government was essential to achieve decoupling: e.g., in China [30,35]. Additionally, decoupling initiatives also come from the private sector or NGOs. Examples of such have occurred in Germany [34], Denmark [28], and the U.K. [36].

However, emerging countries in Latin America, possess a particular political context that might represent a barrier for decoupling [37,38]. Countries at a lower stage of development and with a weaker rule of law tend to have higher dependency on extraction policies augmenting the degradation of natural resources while impacting the RE and the RP of such regions [29]. Furthermore, it appears that there is some indifference and/or inability of these governments to provide sustainable solutions for decoupling $[39,40]$. At the entrepreneurial context, most SMEs of these countries, are operating at "surviving" levels, which force them to avoid large investments besides optimizing their own operations, avoiding any plans for improving their resource efficiency or sustainability initiatives [24].

Following this idea, several authors [32] argued that differences of energy intensity among countries might be associated with the absence of specific policies and lax enforcement mechanisms. The SWIT framework [24] has developed procedures for effective decoupling by inserting CE and a systemic approach to create a circular value ecosystem for a specific region in Mexico [39], that can be extrapolated to other developing countries by creating the proper conditions needed to support the circular systems on these regions.

The countries that have achieved absolute or relative decoupling may have different political context and different stakeholders collaborating for the sustainable development of the region. However, there are some initiatives in common which stand out. Tables 1 and 2 summarize these initiatives and the countries where they have been successfully applied. Table 1 focuses on developed countries while Table 2 focuses on developing countries. 
Table 1. Decoupling initiatives for decoupling in developed countries.

\begin{tabular}{ccc}
\hline Initiative Lead by: & Country & References \\
\hline Financing Programs. & Denmark, Germany, Japan, United Kingdom. & {$[34,41,42]$} \\
Rise in citizens' awareness. & Denmark, Finland, Germany, Japan, United Kingdom. & {$[34,43-45]$} \\
Policies (taxes, veto regulations). & Denmark, Finland, Germany, United Kingdom. & {$[5,34,36,46-48]$} \\
New Technologies & Denmark, Finland, Germany, Japan. & {$[4,34,49-53]$} \\
(digital, biotechnology, renewable energy). & Germany. & {$[34,54]$} \\
Sustainable urban design and development. & &
\end{tabular}

Table 2. Decoupling initiatives for decoupling in developing countries.

\begin{tabular}{ccc}
\hline Initiative Lead by: & Country & References \\
\hline Financing Programs. & India. & {$[34]$} \\
Rise in citizens' awareness. & India. & {$[55]$} \\
Policies (taxes, veto regulations). & China, India. & {$[4,34,35]$} \\
New Technologies (digital, biotechnology, renewable energy). & China, India, South Africa. & {$[4,34,49,50,56]$} \\
Social programs. & China, South Africa. & {$[34,57]$} \\
Sustainable urban design and development. & South Africa. & {$[34]$} \\
\hline
\end{tabular}

Governments, mostly from European countries, have promoted financing programs for sustainable initiatives. These programs have fostered the R\&D investment from the private sector in green technologies [34,42]. For instance, Japan has reduced interest rates for official development assistance loans used in certain environmental projects such as energy-saving technologies, new and renewable energy sources, forest conservation and afforestation, and measures against air pollution [51,52].

Moreover, public awareness has been recognized as an essential part of achieving sustainable development. This has been done through campaigns that manage climate protection and emissions control for school programs (e.g., [34,45]). Evidence of this increasing awareness is found in the literature focused on consumers (e.g., [44]).

Other initiatives for decoupling are seen in the implementation of new policies that increase or create new taxes or prohibit emissions. For instance, China has the objective to achieve "zero growth" in fertilizers and pesticides [35]. Denmark, Finland and the United Kingdom have high taxes, which inhibit the purchase of cars and the consumption of fuels; meanwhile, the logistics of freight transport is improved through optimization of delivery routes $[5,36,46]$.

Furthermore, we should highlight the fact that many countries that have reached relative or absolute decoupling have also established programs for the development of new technologies $[53,56]$ such as digital technologies, biotechnology, nanotechnologies and renewable energies [34]. Technologies are expected to play a crucial role in the shift to a resource-efficient economy through reductions in extraction of non-renewable materials and the diminution of fossil fuel use $[49,50]$.

Finally, other initiatives that have been adopted are social programs and the development of sustainable infrastructure. The former reaches people in precarious conditions $[34,57]$ and provides them with basic needs, such as potable water, ensuring rural power coverage and health centers [34,57]. The latter strategies that apply in rural and urban areas have the objective of designing energy efficient buildings able to be disassembled [34,54]. In this way, the use of raw materials in the construction sector could be extended.

Comparing both tables, it is observable that high impact scientific research focused on decoupling in developing countries is scarce (e.g., [32,58]). Additionally, research performed on decoupling on a global scale has not yet compared their results by region [20]. For example, some studies have found a weak decoupling between energy consumption and GDP in Bogota, Colombia [58]. However, economic development is still dependent on a high degree to the energy consumption, with some exceptions, such as the interesting period between 2004 and 2009 for Brazil when relative decoupling of GDP and $\mathrm{CO}_{2}$ emissions from energy consumption took place [32]. They concluded that this decoupling was due to a carbon intensity reduction and energy matrix diversification (substitution of fossil fuel 
by other types of energy). Nevertheless, the authors recognized that the negative impact of energy intensity might be associated with the lack of specific policies and lax enforcement mechanisms in addressing the efficient use of energy.

\subsection{Limits and Obstacles of Decoupling}

Despite the evidence of decoupling cases, some authors argue that decoupling is not a viable option, instead suggesting that economic growth should remain steady or decrease to achieve sustainable development $[59,60]$.

Evidence of relative decoupling is not difficult to find [21]; however, absolute decoupling seems to be unachievable. This does not mean that decoupling is unnecessary, but rather that it does not provide an alternative to the economic growth dilemma. Resource decoupling has been criticized as a pathway to sustainability given the lack of absolute decoupling, the rebound effect, increased obsolescence, shortened product life spans, consumer confusion concerning eco-efficiency labels, and recycling options, among other problems [59].

It is known that a growing economy becomes more resource efficient, and this efficiency allows decoupling emissions from growth. However, this efficiency gain does not hold true for all environmental indicators like air pollutants, such as sulfur dioxide, which showed an inverted U-shaped curve against economic growth [21]. Additionally, these relationships do not hold for key indicators such as carbon emissions, resource extraction, municipal waste generation and biodiversity loss [21].

Testing how much the GDP could be decoupled from material and energy use, Ward, et al. (2016) [60] found that growth in GDP ultimately cannot be decoupled from growth in material and energy use. Their study showed that the generation of GDP may not be decoupled from resource use. Furthermore, it also noted that GDP is increasingly seen as a poor proxy for societal well-being.

\subsection{Circular Economy as a Vehicle to Achieve Decoupling}

Both in Europe and China, the CE approach has been considered as an intermediate objective toward the achievement of an effective decoupling of economic growth from the consumption of finite resources [3,28]. Following CE principles, it is estimated that with better design and more efficient use of materials, European manufacturers could save US\$630 billion a year by 2025 [61]. CE brings a spectrum of loops in the manufacturing chain that business as usual does not seize (e.g., refurbishment, repairing, reconditioning, upgrading, etc.) [2].

These processes save resources and energy, while reducing environmental impacts [3]. Additionally, remanufacturing comprises additional steps of dismantling, cleaning-up, and quality control, which are absent in manufacturing and yet demanded for more jobs.

In the same vein, it is recognized that these three pillars have lost resilience toward the economic activity of business as usual [2]. They suggested that the industrial practices should improve RE and move toward a CE to become sustainable. Circular economy practices increase the productivity gains, create employment and preserve the natural capital [2,3].

Based on a deep analysis of cases and concepts of the literature regarding decoupling using $\mathrm{CE}$, we argue that sustainable strategies including the $C E$ framework fall short on addressing the three pillars of sustainability in a holistic manner. The SWIT framework, with the proposed circular value ecosystem (CVES), designed for the creation of sustainable wealth from a systemic approach [24], satisfies the design requirements that we have found are fundamental for a decoupling associated to a sustainable wealth creation of the triple bottom line approach.

\section{Research Method}

First, a literature review was conducted to analyze the current state of the art of circular economy engaging with the decoupling of economic growth from environmental impact and social development. The selection of the published articles was performed according to the following criteria: 
(1) chronological order (from 2004-2018) and (2) keywords: "decoupling economic growth" and "circular economy". The literature search was performed in ScienceDirect and Scopus databases. After the duplicates among databases were discarded, the abstracts of each article were reviewed to exclude articles that do not match the topics of interest, remaining just 32 articles. In order to simplify the analysis, the articles were classified into three groups: quantitative (11), case studies (9) and theory-building research (12).

Second, following the results of other studies [28] and our own literature review, a search for information about successful industrial cases in the countries mentioned in both literature reviews was carried out. We listed the practices that each country claim to be performing in order to achieve decoupling and then we selected the most relevant among them (financing programs, raise citizens' awareness, enactment of policies, new technologies development, social programs and sustainable urban design and development). Given that initial information was found on institutional reports, we complemented and further validated it with scientific literature (see Tables 1 and 2).

Third, in the light of the SWIT framework, we evaluate the linear production model and the United Nations Environment Program (UNEP)'s current four decoupling indicators (Figure 1). We found that UNEP's four-factor model falls short to positively address the three pillars of sustainability. Therefore, we extended this model into an eight-factor augmented decoupling model based on the SWIT framework.

In order to further explain the dynamics of the framework and its potential impacts on the triple-bottom line of sustainability [62], the framework was modeled using system dynamics modeling [23,63] supported by the SWIT framework [24]. The SWIT framework is designed to interlink economic systems, policies and strategies, so as to introduce and convert residue, waste, and by-product chains into multiple increasing returns cycles [39].

In order to improve the understanding of our proposal, three deployments have been derived: (1) The current linear chain of production, (2) the original four decoupling indicators regarding economic growth and environmental impact (UNEP's model) and, (3) the cluster generated by the circular value ecosystem (CVES), including the four new indicators to the UNEP's original model.

A special system dynamic software (Vensim PLE) was used to deploy the flows and states of the three deployments, including the proposed eight-factor decoupling model named the CVES. These representations do not have the purpose of running a simulation, but to represent states, flows and feedbacks of the relationships among the decoupling factors.

This section may be divided by subheadings. It should provide a concise and precise description of the experimental results, their interpretation as well as the experimental conclusions that can be drawn.

\section{Analysis of Results}

Based on the inclusion of $\mathrm{CE}$ into the decoupling framework, and from the lessons learned from successful cases, we analyzed whether Latin American countries have developed the proper conditions of circularity to achieve an effective decoupling found on successful countries such as structural enabling conditions (e.g., physical, technological, etc.), strong synergies, social practices, and public policies essential to engage $C E$ mechanisms, and a systemic vision, to support sustainable wealth strategies, on determined regions.

Through the SWIT framework, a circular value ecosystem (CVES) is assembled for the creation of sustainable wealth from a systemic approach [24]. Departing from the UNEP's decoupling mechanism [4], in the following sections we elaborate our proposal of a new circular mechanism based on a systemic approach, designed to effectively decouple economic growth through the circularization of multiple value chains in entire regions with a triple bottom line approach. 


\subsection{Decoupling Approach}

Being a resource-rich country is not a guarantee of positive economic growth [64,65]. Resources have become scarcer and more expensive to extract [22]. The current volatility of raw material prices and their environmental impact end up compromising the economic development of resource-rich countries [64]. This situation creates more damage to natural capital and surrounding communities, consequently creating unstable regional growth [34].

From the previous deployment of Figure 1, of the socio-economic-environmental relationship pertaining to decoupling [4], we propose a new framework, that includes several stakeholders which measures the impact of the circular value ecosystem (CVES) and sustainable innovation approaches on the results of the original variables (see Figure 2).

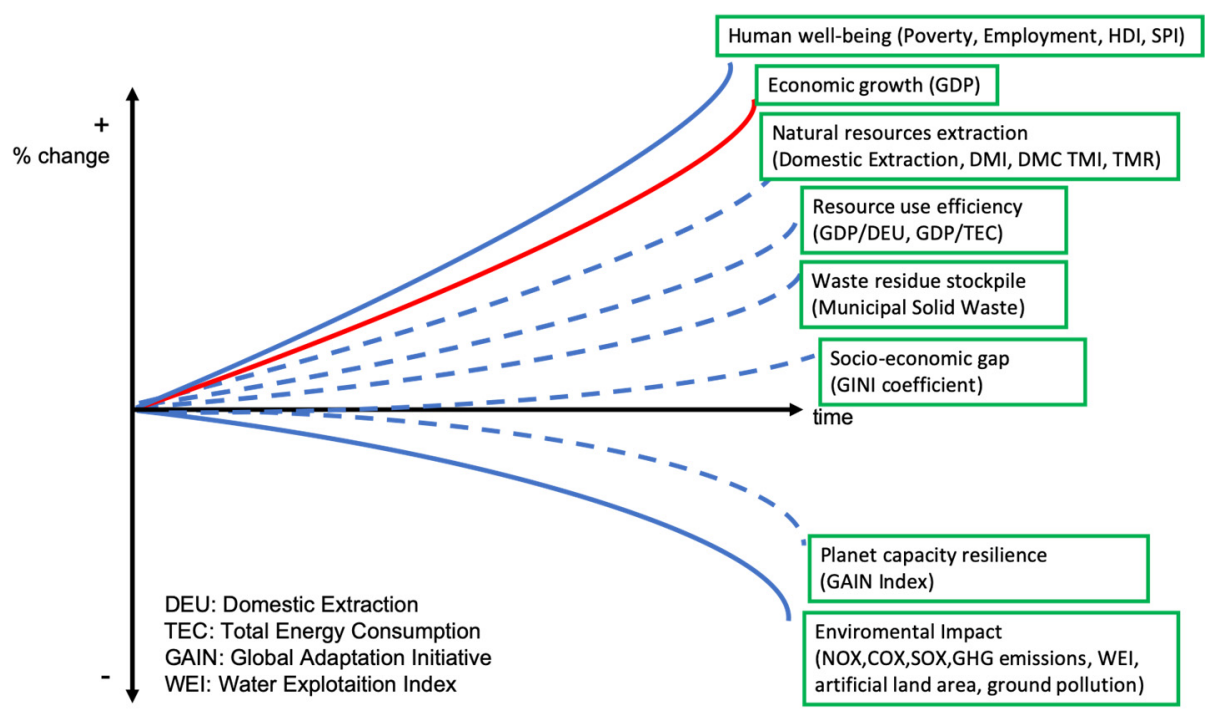

Figure 2. Extended UNEP relationships, with the main metrics for each factor, including: residues, waste and obsolete products, DEU, TEC, GAIN, WEI.

To see how to achieve this synergy between economic growth and environmental impact, we first need to observe the dynamics of the conventional linear chain of production, the traditional "take-make-dispose" or throwaway approach.

In order to understand the dynamics of this case, we used system dynamics [23] as a method to enhance learning and improve our understanding of the complexity of the synergies of the social, environmental and economic systems [66].

\subsection{Linear Chain: Supply-Produce-Distribute-Dispose}

The conventional linear economic production model is based on a "take-make-dispose" approach. This model has endured for decades, given the false belief of infinite resources available to humankind as well as the misconception that ecosystem responses to human use are controllable, predictable and, above all, linear [22,67]. Given these misunderstandings of the dynamics of nature's behavior, policies and strategies have operated wrongfully, focusing mostly in resource and energy efficiency-what we have called in this paper "conventional decoupling".

The linear approach is characterized by demanding the extraction of both virgin natural resources and material inputs (RMI), to supply natural resources for production and subsequent sale of goods on the market. However, after the goods are sold, they continue impacting on the three axes of sustainable development. On the economic side, profits from production return in the form of investments, which eventually intensify productive capacity-requiring even more material or natural (virgin) 
resource inputs for the sake of generating more profits, creating a perverse cycle. Figure 3 shows these relationships among stakeholders of the conventional linear model.

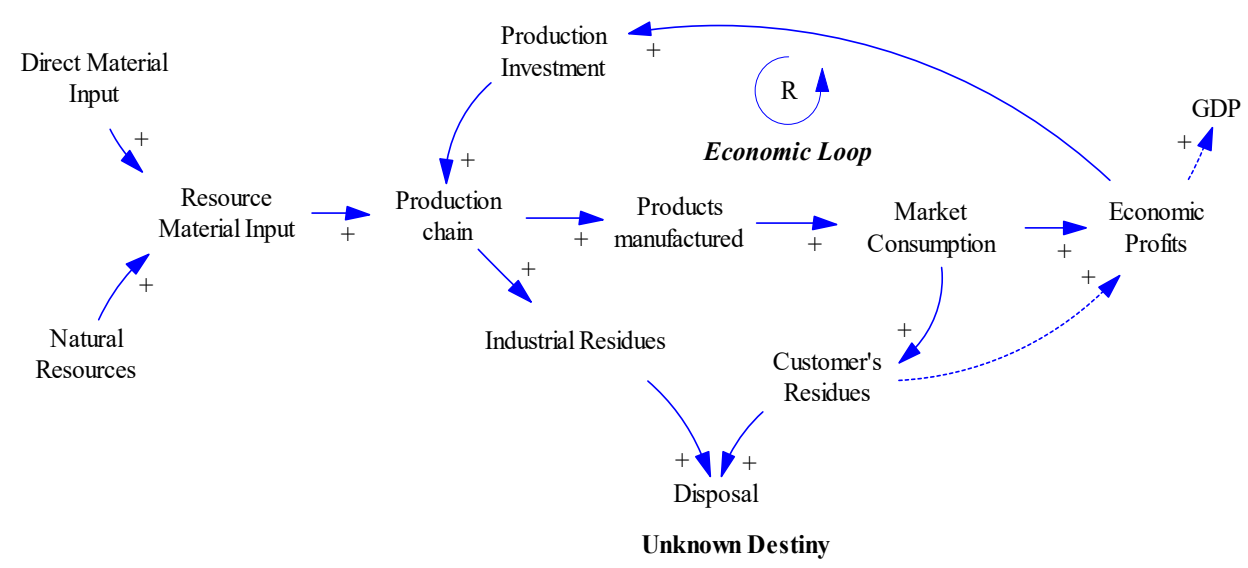

Figure 3. Model showing the dynamics between linear economic returns and the disposal of residual materials.

Despite the economic reinforcing loop that generates economic wealth, it is on the environmental axis, where the downside of the linear model becomes evident as it continues generating large amounts of waste. Such conditions are inevitable without completely redesigning the way companies operate. Therefore, by following the path of both industrial and consumer residues depicted in Figure 3, these elements end up disposed in unknown or undisclosed locations-whether landfills, oceans, or illegally incinerated, generating pollution and eventually damaging the health of natural ecosystems. These residues also represent missed opportunities available for exploitation through non-usual business models.

As this model depicts, the economic gains are generated from the optimization of the linear chain of production that is simultaneously producing more residues, waste, and obsolete products (RWO), whose outputs are regularly excluded in terms of material, energy, or financial flows. In other words, this model represents a production system where economic profits are completely coupled with resource extraction while excluding the other two actors of the ecosystem equation.

\subsection{Basic Decoupling Model}

Translating the basic UNEP graph (Figure 1) into a system dynamics relationship model, new stakeholders are added to the linear model, generating additional behaviors represented mainly by extra feedback loops. These extra feedback loops include productive activities on the social and environmental pillars. Figure 4 shows the new dynamics of the stakeholders.

At the epicenter of Figure 4 lies the main variable of interest: economic growth, which is linked to the other two subsystems. Economic growth is fostered over time through increasing new jobs and, in consequence, a better human well-being, thereby narrowing, over the long run, the socioeconomic gap, and incentivizing market consumption as well. The increase in market consumption creates a larger supply that, in turn, leads to greater economic growth. This dynamic represents a reinforcing loop that has a positive impact on both social and economic systems.

For the economy to grow, more resources are required, and this need often generates negative environmental impacts. That need leads to a higher recovery of expenses (i.e., remediation costs) that, in turn, have a decelerating effect on economic growth. Consequently, the overall dynamic of this situation represents a balancing loop where "economic growth" is included. 


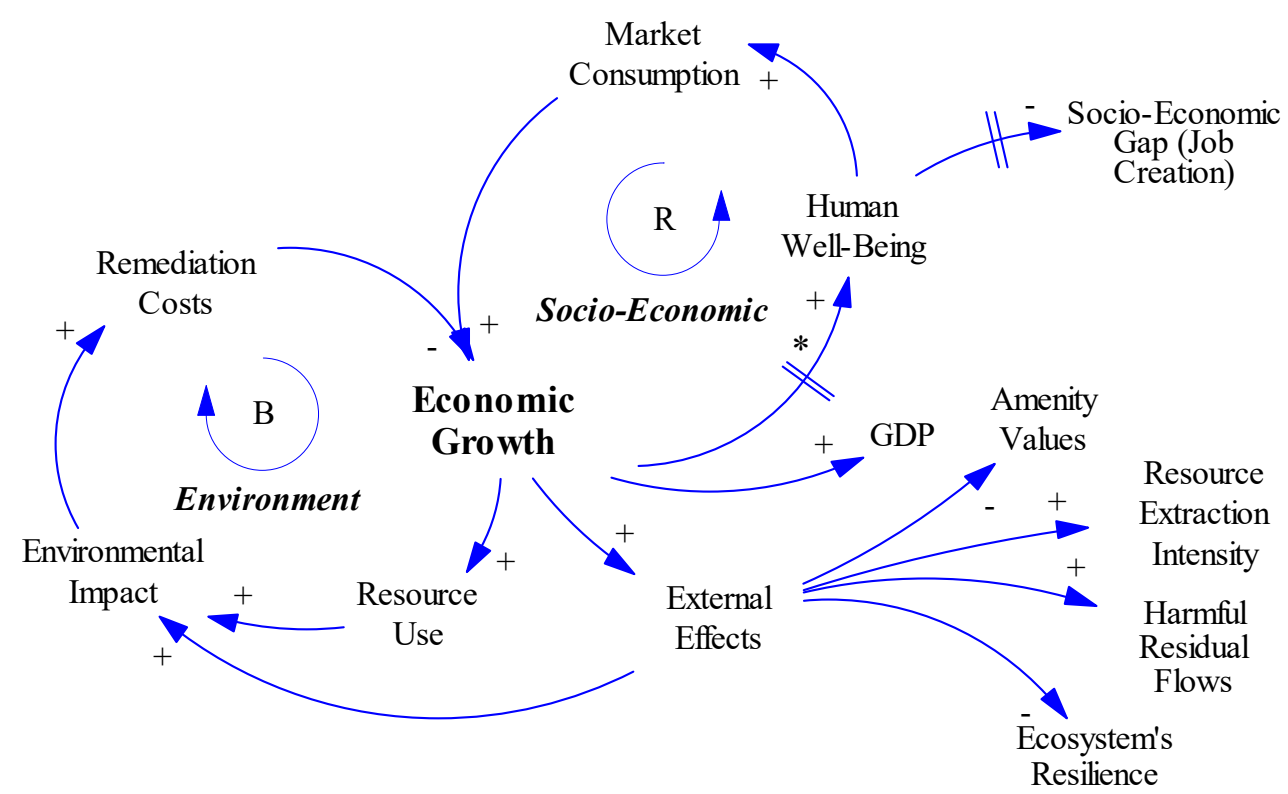

Figure 4. Model showing the main relationships of basic decoupling of the United Nations Environment Program [4]. * Denotes a lag between the relationship of the two variables in the model.

Notwithstanding this outcome, there are other impacts outside these dynamics. Ignited by economic growth, too, are external effects such as an increase in resource extraction intensity and harmful residual flows, as well as a reduction of the ecosystem's resilience. Finally, and in parallel, natural aesthetics are impacted negatively.

In summary, the current economic growth needs considerable amounts of natural and processed materials, while profits, if properly shared, may create jobs, public assets, and improve the quality of life and well-being - which will perhaps not occur, if absent of proper regional conditions at the expense of larger negative environmental impacts, or lack of rule of law, for instance.

The previous sequence of events may justify economic growth. However, it alters both natural capital and the well-being of the inhabitants of a determined region. It is, in the long term, a perverse cycle.

\subsection{A circular Decoupling Model}

From previous experiences, scholars have found that it is necessary to discover efficient mechanisms that are capable to effectively decouple economic growth from environmental decay $[3,21,22]$, thus generating sustainable increasing returns (i.e., value for the three systems) that come from other sources.

A key issue for an effective decoupling strategy is to change the conventional cultural paradigm of creating economic growth, based on the business-as-usual model. Current businessmen and entrepreneurs manage environmental issues as a negative externality, the result of a forced regulation, or simply as an obliged global trend, instead of being part of their core business strategy or a holistic vision of regional development [68].

Integrating environmental resilience, new job creation, social gap reduction and economicallyefficient returns within a sustainable value creation model, leads to redesigning and restructuring linear value chains, and the production of new synergies among industrial ecology stakeholders and producer-consumer-nature ecosystems [39].

Seeking out new approaches, successful cases and practices, the scientific research literature has proposed the use of a CE model as a mechanism to increase natural RE and RP [3,28]. It is suggested that the CE may help "incremental environmental returns" from natural resource extraction and productivity usage efficiencies. 


\subsection{Dynamics of the Circular Value Ecosystem Engagement}

From the previous deployment of the socioeconomic-environmental indices for decoupling seen in Figure 2, and from the above statements, we propose new dynamics to articulate how stakeholders may be included on a new model of decoupling.

The following model of system dynamics (Figure 5), depicts how the circular value ecosystems (CVES) approach of the SWIT framework [24] may increase natural RP $[28,69]$ while it generates multiple businesses in order to create economic additional resources for the community.

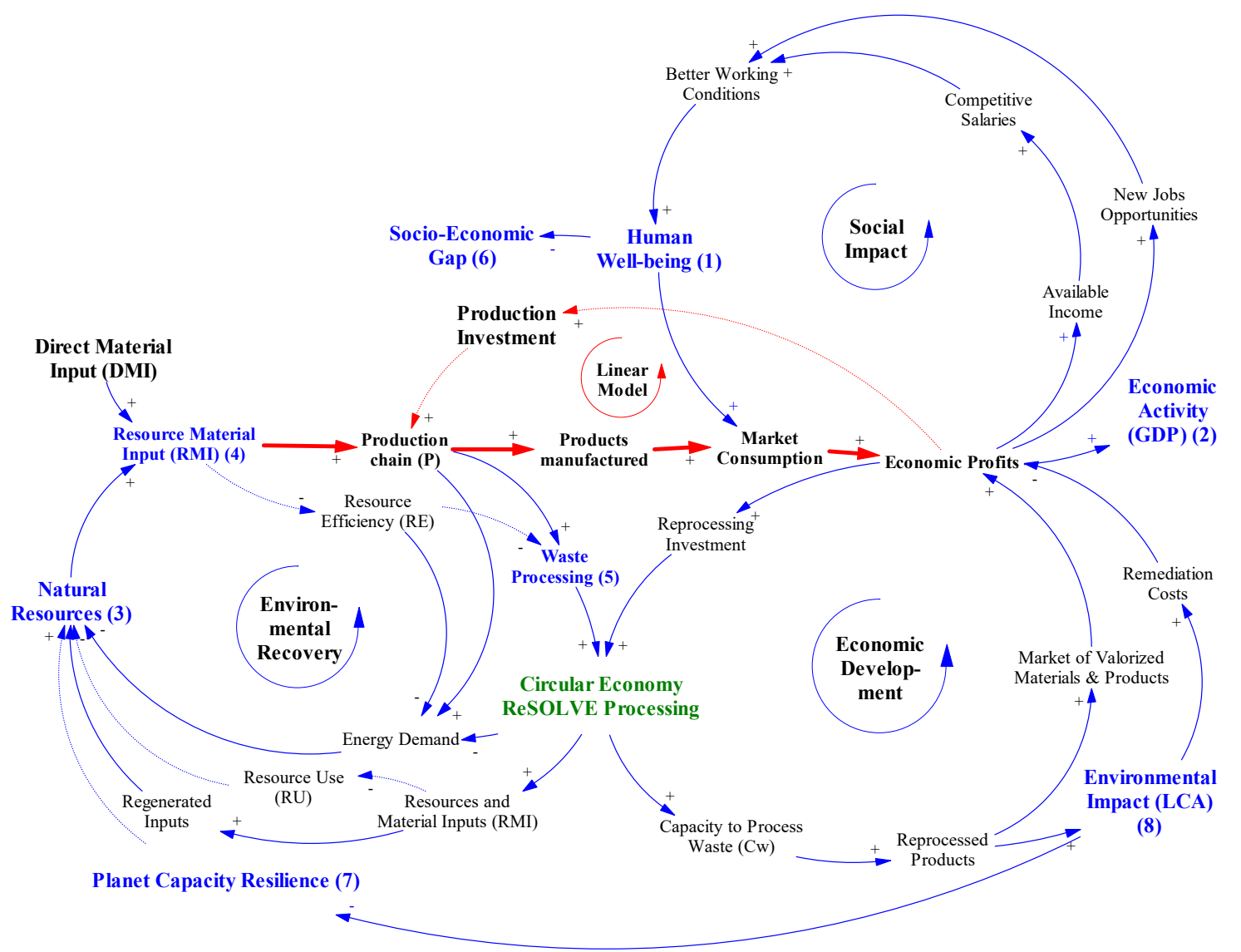

Figure 5. Dynamic mental model of how the Circular Economy approach can be engaged into the proposed eight-factor decoupling framework.

Previous models illustrated in Figures 3 and 4 depicted no decoupling (i.e., a linear chain) or relative decoupling, respectively. Furthermore, they lacked a systemic enabler to decouple economic growth and profits from the extraction of natural virgin materials. We maintain that a CE might be such an enabler given that, by definition, it is a global economic model that aims to decouple economic growth and development from the consumption of finite resources [61,70].

Therefore, by incorporating the systemic methodologies of the CVES into the previous models, the integration of the economic, social, and environmental dynamics is possible, and has the potential to change the performance of a region. These changes can be identified through several feedback loops, as follows.

These dynamics start from the linear value chain depicted by thick arrows in Figure 5 which generates great amounts of residues, on the one hand, during production, in the form of emissions and solid wastes; and on the other hand, after consumption in the form of obsolete products. These residues and waste represent a business opportunity available through fundamentally redesigning industrial production [71]. 
Therefore, the first feedback loop enabled by CE begins with the waste generated during production that, rather than being landfilled, is now inserted into a new economic model. It is an economy where residuals once again enter the value chain as regenerated inputs, substituting natural resource extraction and/or the use of non-renewable energy. This dynamic is enabled by innovative processes from non-usual business models such as the CE ReSOLVE framework [26,72,73]. The result is a balance loop that increases production while decreasing the necessity of extracting more virgin natural resources.

The same logic applies to obsolete products that can be transformed into feedstock for the same industry that initially manufactured them through a cradle-to-cradle (C2C) approach [74]. When unable to be injected directly as a physical input for the process, they can also be transformed into energy, which can reduce the need for additional capital goods. However, it is certainly preferable that products and components be kept at their highest value at all times.

Another interesting dynamic, portrayed by a wider loop in the diagram, focuses on the economic rationale facilitated by the $\mathrm{CE}$. Following a business rationale, $\mathrm{CE}$ enables the reprocessing of residues through the incorporation of appropriate technologies [3] closing the linear production chain. Hence, an increase of reprocessed obsolete products is accompanied by a growth of new jobs [3] that create valuable materials and products that are able to spur economic profits. These profits can be invested into new reprocessing technologies aligned with CE principles, or can increase the capacity to process waste and/or reprocess inputs while lowering waste disposal costs incurred by landfill use or incineration processes [75], thus generating a virtuous cycle [76]. Therefore, the process leads to a reduction in overall environmental impacts, mitigating remediation costs and thus, overall, increasing economic profits.

Such atypical business models decrease considerably environmental impacts by diverting residues and waste from incineration sites or landfills; instead, they serve as a resource or energy inputs. In addition, they build up the planet's resilience and recovery while lowering the possibility of being subject to fines and regulatory costs. Moreover, if properly designed, this management of RWO creates a new circular value ecosystem that produces economic profits and controls inputs and production. Moreover, it reduces environmental damage by using suitable waste and residues management, appropriate technologies and governance [39].

Although the discussion on reusing waste is not new [2,3,28], our proposal empowers the process of decoupling by the insertion of the circular value ecosystem. This circular value ecosystem is not only a path to reduce material consumption, but it has a direct impact to increase the economic activity through highly value-added non-usual business models [22,28,77].

The current strategies are focused on reducing the amount of resources and energy used and not on wealth creation (see Tables 1 and 2). Finally, but no less important, are the social impacts of a CE approach taken on a tangible aspect through several positive externalities in the form of new business ventures that reinforce the demand for skilled labor [3]; increasing economic indicators as GDP, on the one hand, and human well-being on the other. The latter narrows the socioeconomic gap and fosters reasonable consumption of resources [78].

In consequence, the purpose of the circular decoupling framework, is to show how to augment natural RE and RP using a CE value-added dynamic approach, that is capable of (1) decreasing significantly the demand for natural resources and energy; (2) transforming waste, residues, and obsolete products, into valuable assets; (3) reducing the socioeconomic gap; (4) reducing the environmental degradation; and, consequently, and (5) increasing natural ecosystems resilience and their cycles of operation.

Overall, the decoupling process provided by the above dynamic interaction of multiple stakeholders, enabled by the CE perspective, will have a positive influence on the regional resilience, based on a sustainable wealth creation that benefits the stakeholders of the three axes of the natural ecosystem: economic development, social justice, and environmental recovering [79]. 
Despite the complexities involved in the process, the conceptual model presented in this study shows the key dynamics to be taken into account when seeking decoupling. The correct "clustering" of actors, linear chains, analysis, processes, residues, wastes, appropriate technologies and business models, are the most important success factors for an effective decoupling. These will be discussed in the following section, where the CVES model will show the interactions and experiences of leading countries that have applied the circular economy principles, the systemic approach, and the key stakeholders of the process of decoupling, creating a robust, circular, value-added system capable to be replicated in developing countries.

\section{Discussion}

From the proposed model in Figure 5, we can observe the dynamics of integrating CE into the decoupling process, where residues, waste, and obsolete products (RWO) are integrated into more valuable cycles. The linear production chain manufactures products and makes economic profits but, at the same time, the reevaluated goods are reinserted to support economic growth, while simultaneously reducing the use of natural resources by substituting them with reprocessed input materials. After analyzing these dynamics, we can validate the following statement:

A CE approach can be inserted into the linear production chain, creating a CVES dynamics, which reduces the total material requirements. Simultaneously, CE transforms the impact generated by residues and waste, into aggregated economic increasing returns. Furthermore, through the implementation of a cluster of new non-usual businesses, a circular value-added system increases economic growth as well as natural RE and RP, allowing environmental recovery, social inclusion and, consequently, generating new venture capital that benefits everyone.

\subsection{Lessons Learned from the Decoupling of Leading Countries}

We have observed that any exercise of circularity needs appropriate regional conditions $[70,80]$. Otherwise, firms and supporting institutions will be unable to implement any decoupling strategy.

After the analysis of countries that have achieved some progress in decoupling (Tables 1 and 2), we have found that countries like China, Japan, and India have made exceptional strides improving RE. The findings from these countries may become benchmarks for the current situation of some Latin American countries. We can summarize these findings in three statements.

First, none of the countries, which have achieved a certain degree of decoupling, have full-fledged policies for achieving comprehensive resource and impact decoupling that lead to create true sustainable wealth $[29,30]$. Second, the concepts of RE, RP, dematerialization, and material flows has entered mainstream policy development awareness campaigns (e.g., [34]). Third, sustainable awareness campaigns and financing of sustainable projects increase the motivation of citizens and the private sector for sustainable development [34].

After identifying some of the world's best practices, it is of great relevance to see if similar situations can be found in Latin America.

\subsection{The Situation of Latin America, Regarding Resource Efficiency (RE) and Resource Productivity (RP) Factors}

In the last decades, Latin American and Caribbean countries have improved their economic and social indicators considerably [81,82]. Between 2002 and 2014, this region has grown economically with an average rate of $3.32 \%$ [81]. However, since 2015, the region reveals an increase in the general levels of poverty and extreme poverty; in 2017, more than 187 million people were still living in poverty and another 62 million under extreme poverty [81].

Moreover, the agricultural activities are highly sensitive to climate change effects. In Latin America and the Caribbean (LAC), this sector contributed around 5\% of GDP in 2012, concentrated $16 \%$ of the employed population and represented around 23\% of regional exports [83]. Climate change evidence from this region, as in the rest of the world, shows that its impacts on agriculture can already be observed and there is a high probability that they could be accentuated in the future $[84,85]$. This will 
compromise the economy of the region, the food security and subsistence for the population in rural areas, which in Latin America represents 22\% of the total population [86]. This high dependency on the primary activity, the threat that climate change represents and the necessity to increase the social welfare of the region, is evidence of the need for a decoupling mechanism that may prioritize wealth creation.

Due to its particular political context [37,38], decoupling economic growth from resource use and environmental impacts in LAC seems to have larger impediments than in European or emerging Asian countries. For instance, Brazil, Colombia, and Paraguay have had the resources and initiatives to develop a sustainable production of biofuels from palm oil [87], a greener source of energy. This kind of conduct can achieve relative or absolute decoupling. Nevertheless, absent rule of law, high corruption, poor regulation, poor connectivity and weak control mechanisms, contributed to the loss of relevant and costly natural capital, such as that which happened at the Amazon forest [87]. An example of this situation has been the liberalization of foreign trade, like in Cordoba, Argentina, where large corporate farmers bought the land of smaller ones and do not rotate soybean crops due to significant Chinese demand for soybeans. These actions led to the erosion of a vast extension of land, and small farmers became unemployed in the long run [88]. This situation destroyed the virtuous gains of circularity.

The previous examples show that the best practices from leading countries cannot be directly implemented to Latin American countries. They might be observed and adapted with certain cautiousness. To successfully achieve decoupling in developing countries, it is necessary to implement it in a holistic manner through "key enabling conditions" that most of these countries are incapable to reach. Examples of such conditions involve strengthening regulatory institutions, a strong rule of law, achieving an articulated clustering strategy among stakeholders and an extended use of emerging technologies (e.g., virtualization, robotics, analytics, clean technologies, biotechnology, nanotechnology, etc.) for the transformation processes, and a well-trained systemic leadership [27,89]; all these, in order to lead "sustainable" educated citizens and policy makers [70,80]. In most cases, in the end, the decoupling mechanism is reduced to develop a culture of growing, maintaining a balance of the three dimensions of the natural ecosystem.

\subsection{The Influence of Institutions on Decoupling Initiatives}

Based on our literature review and findings, we cannot neglect that the context of the countries is dissimilar and affects the implementation and efficiency of decoupling initiatives. This argument is supported and widely discussed by institutional theory [90,91]. In emerging economies, it has been examined and supported that variables as GDP and FDI have a positive relationship with the quality of institutions [92]. In Table 3, we used some of the institutions from previous research of institutional theory in developing countries [92] and discussed how they affect decoupling in developing countries based on our literature review.

In summary, for developing countries, such as the Latin America region, great attention should be dedicated to the decoupling of economic growth from the extraction of natural resources and from the generation of excessive residues and toxic materials. For most of them, their large relevant economic activity depends from the extraction and from the manufacturing of products that have a significant impact on the environment and on the way of living of their population. However, the engagement of circular economy practices is difficult and costly, because, in certain cases, success depends on having: proper enabling structural conditions (e.g., connectivity, systemic culture, enabling technologies, etc.); capabilities to maintain strong industrial ecology synergies; governability; holistic management of clusters; and public policies with a strong sense of sustainability and quality of institutions (e.g., voice and accountability, government effectiveness, regulatory quality, rule of law, control of corruption). 
Table 3. Institutions and their effect in decoupling initiatives.

\begin{tabular}{|c|c|c|}
\hline Institution & Definition & $\begin{array}{l}\text { How the Institution Affects Decoupling } \\
\text { in Developing Countries (DCs). }\end{array}$ \\
\hline Voice and accountability & $\begin{array}{l}\text { The extent to which citizens have a } \\
\text { say in government, freedom of } \\
\text { expression, freedom of association } \\
\text { and freedom of the media. }\end{array}$ & $\begin{array}{l}\text { A diversity of developing countries has been } \\
\text { distinguished for a limited freedom of speech } \\
\text { and information. This might affect the public } \\
\text { awareness and citizens' demands for } \\
\text { sustainable strategies. }\end{array}$ \\
\hline Government effectiveness & $\begin{array}{l}\text { Quality of public services and the } \\
\text { insulation of the civil service from } \\
\text { political pressures. }\end{array}$ & $\begin{array}{l}\text { This parameter affects widely the effect of the } \\
\text { introduction of new technologies and programs } \\
\text { for decoupling economic growth from natural } \\
\text { resources extraction. This also discourages the } \\
\text { citizens to participate. }\end{array}$ \\
\hline Regulatory quality & $\begin{array}{l}\text { Government's ability to generate } \\
\text { policies and regulations that } \\
\text { promote development in the } \\
\text { private sector. }\end{array}$ & $\begin{array}{l}\text { If the government does not design bold policies, } \\
\text { and durable self-financial strategies, } \\
\text { the sustainable initiatives could easily be } \\
\text { focused on efficiency and, after a matter of time, } \\
\text { obtain a rebound effect and disappear. }\end{array}$ \\
\hline Rule of law & $\begin{array}{l}\text { How well actors in a nation abide } \\
\text { by the code of law. }\end{array}$ & $\begin{array}{l}\text { One of the major factors to support the } \\
\text { implementation of decoupling strategies is } \\
\text { "trust on the institutions". If enforcement of law } \\
\text { does not exist, or is poorly implemented, } \\
\text { as is common in developing countries, } \\
\text { the application of regulations and normativity } \\
\text { is impossible. In consequence, this institution is } \\
\text { a key success factor for achieving decoupling in } \\
\text { developing countries. }\end{array}$ \\
\hline Control of corruption & $\begin{array}{l}\text { The extent to which public goods } \\
\text { are exploited by private } \\
\text { individuals. }\end{array}$ & $\begin{array}{l}\text { The institution, which applies this mechanism, } \\
\text { is linked to the rule of law. The lack of } \\
\text { institutions promoting transparency and law } \\
\text { enforcement in developing countries affect the } \\
\text { management of large financing programs and } \\
\text { implementation of large projects that favor } \\
\text { economic growth versus sustainable } \\
\text { development. To have a sustainable region is } \\
\text { necessary to have a healthy economy and } \\
\text { corruption does not help, mainly in DCs. }\end{array}$ \\
\hline
\end{tabular}

\section{Conclusions}

Decoupling economic growth from environmental impact resource efficiency represents a complex and challenging task. The proposed model based on a systemic view of growth represents a viable alternative. Despite best practices on leading, developed countries have taught us that although achieving a certain degree of decoupling is possible, it certainly cannot be applied in the same way in developing countries as the context greatly varies. However, we can highlight some contributions obtained from the analysis done in this study.

For instance, the model proposes the assembly of a circular value ecosystem, composed of a cluster of regional stakeholder synergies with a positive impact on the triple bottom line [62]. This is an alternative sustainable wealth creation mechanism for all stakeholders that goes beyond a simple product or production system by focusing on entire regions.

Additionally, despite there being evidence that CE principles increase Resource Efficiency and Resource Productivity, it is not enough for achieving decoupling in developing countries such as Latin American countries. As we have shown on our model, there is a need for a more holistic approach to address the three pillars for the creation of sustainable wealth. Therefore, the proposed CVES approach fulfills the design requirements that we have found are needed for achieving sustainable wealth creation through decoupling. 
Moreover, the present research has contributed to further advance the understanding of the decoupling process. It has shed light on the different indicators (best practices) of developed countries related to decoupling and how they might or might not apply to Latin American countries. In addition, it has complemented UNEP's decoupling indicator model by focusing on how to positively address the three pillars of sustainability in developing countries.

Furthermore, the present research encourages researchers to use methodologies able to deal with complexity such as system dynamics modelling. Decoupling challenges requires taking into account multiple stakeholders, feedback loops and other heterogeneous dynamics. The analysis of these intricated interactions are of great value to unravel decoupling opportunities.

Beyond these dynamics, the cultural (e.g., environmental awareness), institutional, technological and political (e.g., rule of law) factors are among the most fundamental when implementing decoupling strategies and regional policies. However, in order for decoupling to be successfully implemented, we contend that there must be a systemic enabler. In line with this, we also stressed the importance of the role of non-usual business models based on the valorization of residues, waste and obsolete products coupled with a holistic vision of regional development as the key enablers of regional decoupling based on circular economy. These new types of non-usual business models effectively internalize externalities through the creation of multiple businesses, which foster economic development for communities.

The proposal of this study could be summarized in two main objectives. First, to identify which factors promote decoupling, based on the best practices from the leading countries; and second, to propose a CE framework based on a circular value system which has contributed to our understanding on how to implement decoupling and increase RE practices in developing countries, which are economically highly dependent on the extraction of their natural resources. With this circular value-added ecosystem, we propose to transform waste, residues, and obsolete products into valuable goods preventing the adverse consequences of linear economic growth and the corresponding deterioration of natural resources.

RE and RP cannot be achieved if the efficiency of production is reached only by traditional linear procedures. In traditional manufacturing industries (even with the digitalized industry 4.0, AI, robotics and other information technologies), if the economy grows, the use and abuse (e.g., some extraction cases of deliberate production of debris and contaminated tailings) of resources also grows-sometimes faster than economic growth itself (e.g., $[93,94])$ Thus, innovative procedures such as the circular value ecosystem (CVES) must be implemented in order to achieve better resource efficiency while prioritizing sustainable wealth creation.

However, we are conscious that reducing resource use and energy demand is a prerequisite for applying CE practices, and that although most CE models (e.g., remanufacturing, renovating, reusing, etc.) require additional investment, innovative processes and sustainable-aligned policies, we still think that decoupling can be achieved while generating benefits for the subsystems of the natural ecosystem, all under an economic competitive framework.

Thus, we offer the systemic approach of the CVES for policy makers, businesspersons and academicians for developing countries, to understand what leading regions are doing in creating effective strategies for augmenting natural resource efficiency. Additionally, through the dynamics of the circular system approach, of the main model of decoupling, (Figure 5), several alternatives may be generated. Decision makers of developing countries may: (1) substitute the consumption of natural resources with processed resources; (2) produce alternative economic increasing returns; (3) reduce the impact on the environmental damage, transforming waste and residues into valuable assets; or (4) create self-sustainable wealth for the economic, environmental, and social development of most stakeholders of these regions; that is, decoupling economic growth from natural resource use, creating a sustainable wealth for all. 


\section{Limitations}

The present research encompasses a preliminary analysis and a well-supported proposal. It represents the first step for understanding the complexity of the decoupling process, by using a systems approach. Further developments would include the system dynamics model validation, application, and simulations. This, in order to allow a deeper quantitative analysis of the impacts identified and the evaluation of possible strategies to support the implementation of a decoupling mechanism based on CE principles and circular value-added systems business models. Furthermore, we acknowledge that some data might not be scientifically reviewable given the relative novelty of the topic, and since much of the information is still being generated in the Latin American context. Future research could focus on a more extensive quantitative analysis derived from the observation of the LAC region behavior, and find under which conditions the CVES can be assembled to achieve a successful economic growth, disaggregated of the resource use and environmental impact, of this large region. Additionally, the effectiveness of this model should be tested in the light of negative externalities belonging to a specific city or country. Finally, future research should focus on assigning a monetary value to externalities and to include them into the model.

Author Contributions: Conceptualization, C.S., E.A.; methodology, E.A., B.B.; investigation, C.S., E.A., B.B.; writing—original draft preparation, C.S., E.A., B.B.; writing—review and editing, C.S., E.A., B.B.; All authors have read and agreed to the published version of the manuscript.

Funding: This research received no external funding

Conflicts of Interest: The authors declare no conflict of interest.

\section{References}

1. Vieira, M.D.; Ponsioen, T.C.; Goedkoop, M.J.; Huijbregts, M.A. Surplus Cost Potential as a Life Cycle Impact Indicator for Metal Extraction. Resources 2016, 5, 2. [CrossRef]

2. Leuenberger, H.; Mehdi, H. Sustainable Production: Can industry go truly green? Development 2015, 58, 492-499. [CrossRef]

3. Stahel, W.R. Policy for material efficiency-Sustainable taxation as a departure from the throwaway society. Philos. Trans. R. Soc. A Math. Phys. Eng. Sci. 2013, 371, 20110567. [CrossRef] [PubMed]

4. United Nations Environmental Programme. Decoupling Natural Resource Use and Environmental Impacts from Economic Growth; International Resource Panel: Paris, France, 2011.

5. Tapio, P. Towards a theory of decoupling: Degrees of decoupling in the EU and the case of road traffic in Finland between 1970 and 2001. Transp. Policy 2005, 12, 137-151. [CrossRef]

6. Giampietro, M. On the Circular Bioeconomy and Decoupling: Implications for Sustainable Growth. Ecol. Econ. 2019, 162, 143-156. [CrossRef]

7. Lonca, G.; Bernard, S.; Margni, M. A versatile approach to assess circularity: The case of decoupling. J. Clean. Prod. 2019, 240, 118174. [CrossRef]

8. Stål, H.I.; Corvellec, H. A decoupling perspective on circular business model implementation: Illustrations from Swedish apparel. J. Clean. Prod. 2018, 171, 630-643. [CrossRef]

9. Liu, X.; Guo, P.; Nie, L. Applying emergy and decoupling analysis to assess the sustainability of China's coal mining area. J. Clean. Prod. 2020, 243, 118577. [CrossRef]

10. Madden, B.; Florin, N.; Mohr, S.; Giurco, D. Using the waste Kuznet's curve to explore regional variation in the decoupling of waste generation and socioeconomic indicators. Resour. Conserv. Recycl. 2019, 149, 674-686. [CrossRef]

11. Boulding, K.E. The economics of the coming spaceship Earth. In The Earthscan Reader in Environmental Economics; Earthscan: London, UK, 1992; pp. 27-35.

12. Lehmann, S. Implementing the Urban Nexus approach for improved resource-efficiency of developing cities in Southeast-Asia. City Cult. Soc. 2018, 13, 46-56. [CrossRef]

13. Flachenecker, F.; Rentschler, J. Investing in Resource Efficiency: The Economics and Politics of Financing the Resource Transition; Springer: Cham, Switzerland, 2018; ISBN 3-319-78867-1. 
14. Huang, T.; Shi, F.; Tanikawa, H.; Fei, J.; Han, J. Materials demand and environmental impact of buildings construction and demolition in China based on dynamic material flow analysis. Resour. Conserv. Recycl. 2013, 72, 91-101. [CrossRef]

15. Lin, C.S.K.; Pfaltzgraff, L.A.; Herrero-Davila, L.; Mubofu, E.B.; Abderrahim, S.; Clark, J.H.; Koutinas, A.A.; Kopsahelis, N.; Stamatelatou, K.; Dickson, F.; et al. Food waste as a valuable resource for the production of chemicals, materials and fuels. Current situation and global perspective. Energy Environ. Sci. 2013, 6, 426-464. [CrossRef]

16. Neufeld, L.; Stassen, F.; Sheppard, R.; Gilman, T. The new plastics economy: Rethinking the future of plastics. In Proceedings of the World Economic Forum, Davos-Klosters, Switzerland, 20-23 January 2016.

17. Cohen, G.; Jalles, J.T.; Loungani, P.; Marto, R. The long-run decoupling of emissions and output: Evidence from the largest emitters. Energy Policy 2018, 118, 58-68. [CrossRef]

18. The Energy Conservation Center, Japan. Top Runner Program: Developing the World's Best Energy-Efficient Appliance; The Energy Conservation Center: Tokyo, Japan, 2008.

19. Bringezu, S.; Schütz, H.; Steger, S.; Baudisch, J. International comparison of resource use and its relation to economic growth: The development of total material requirement, direct material inputs and hidden flows and the structure of TMR. Ecol. Econ. 2004, 51, 97-124. [CrossRef]

20. Krausmann, F.; Gingrich, S.; Eisenmenger, N.; Erb, K.-H.; Haberl, H.; Fischer-Kowalski, M. Growth in global materials use, GDP and population during the 20th century. Ecol. Econ. 2009, 68, 2696-2705. [CrossRef]

21. Jackson, T. Prosperity without Growth: Economics for a Finite Planet; Routledge: New York, NY, USA, 2009; ISBN 1-136-54678-2.

22. Webster, K. The Circular Economy: A Wealth of Flows; Ellen MacArthur Foundation Publishing: Cowes, UK, 2017; ISBN 0-9927784-6-8.

23. Sterman, J. Business Dynamics; Irwin/McGraw-Hill: New York, NY, USA, 2010; ISBN 0-07-231135-5.

24. Scheel, C. Beyond sustainability. Transforming industrial zero-valued residues into increasing economic returns. J. Clean. Prod. 2016, 131, 376-386. [CrossRef]

25. Lacy, P.; Rutqvist, J. Waste to Wealth: The Circular Economy Advantage; Springer Heidelberg: Berlin, Germany, 2016; ISBN 1-137-53070-7.

26. Lewandowski, M. Designing the Business Models for Circular Economy-Towards the Conceptual Framework. Sustainability 2016, 8, 43. [CrossRef]

27. Scheel, C.; Pineda, S. Innovacities: Impact of Regional Innovation Systems on the Competitive Strategies of Cities; Editorial UTADEO: Bogotá, Colombia, 2017; ISBN 958-725-219-5.

28. Ghisellini, P.; Cialani, C.; Ulgiati, S. A review on circular economy: The expected transition to a balanced interplay of environmental and economic systems. J. Clean. Prod. 2016, 114, 11-32. [CrossRef]

29. Wang, H.; Hashimoto, S.; Yue, Q.; Moriguchi, Y.; Lu, Z. Decoupling Analysis of Four Selected Countries. J. Ind. Ecol. 2013, 17, 618-629. [CrossRef]

30. Yu, Y.; Chen, D.; Zhu, B.; Hu, S. Eco-efficiency trends in China, 1978-2010: Decoupling environmental pressure from economic growth. Ecol. Indic. 2013, 24, 177-184. [CrossRef]

31. Voet, E.; Oers, L.; Nikolic, I. Dematerialization: Not Just a Matter of Weight. J. Ind. Ecol. 2004, 8, 121-137. [CrossRef]

32. De Freitas, L.C.; Kaneko, S. Decomposing the decoupling of CO2 emissions and economic growth in Brazil. Ecol. Econ. 2011, 70, 1459-1469. [CrossRef]

33. Anand, S.; Sen, A. Human Development Index: Methodology and Measurement; Occasional Papers; Human Development Report Office: New York, NY, USA, 1994; pp. 1-19.

34. Hennicke, P.; Khosla, A.; Thakur, M.S.; Wilts, H. Decoupling Economic Growth from Resource Consumption; Internationale Zusammenarbeit (GIZ) GmbH: Berlin, Germany, 2014; pp. 1-36.

35. Zhang, K.-M.; Wen, Z.-G. Review and challenges of policies of environmental protection and sustainable development in China. J. Environ. Manag. 2008, 88, 1249-1261. [CrossRef] [PubMed]

36. Alises, A.; Vassallo, J.M.; Guzman, A.F. Road freight transport decoupling: A comparative analysis between the United Kingdom and Spain. Transp. Policy 2014, 32, 186-193. [CrossRef]

37. Nicholls-Nixon, C.L.; Davila Castilla, J.A.; Sanchez Garcia, J.; Rivera Pesquera, M. Latin America management research: Review, synthesis, and extension. J. Manag. 2011, 37, 1178-1227. [CrossRef]

38. Silva, E. Thinking Politically about Sustainable Development in the Tropical Forests of Latin America. Dev. Chang. 1994, 25, 697-721. [CrossRef] 
39. Aguiñaga, E.; Henriques, I.; Scheel, C.; Scheel, A. Building resilience: A self-sustainable community approach to the triple bottom line. J. Clean. Prod. 2018, 173, 186-196. [CrossRef]

40. Williams, A. Shining a Light on the Resource Curse: An Empirical Analysis of the Relationship Between Natural Resources, Transparency, and Economic Growth. World Dev. 2011, 39, 490-505. [CrossRef]

41. Klaassen, G.; Miketa, A.; Larsen, K.; Sundqvist, T. The impact of R\&D on innovation for wind energy in Denmark, Germany and the United Kingdom. Ecol. Econ. 2005, 54, 227-240.

42. Wiesenthal, T.; LeDuc, G.; Haegeman, K.; Schwarz, H.-G. Bottom-up estimation of industrial and public R\&D investment by technology in support of policy-making: The case of selected low-carbon energy technologies. Res. Policy 2012, 41, 116-131.

43. Gotoh, S. Japan's Changing Environmental Policy, Government Initiatives, and Industry Responses. In The Industrial Green Game: Implications for Environmental Design and Management; National Academy Press: Washington, DC, USA, 1997; pp. 234-253.

44. Walker, H.; Brammer, S. Sustainable procurement in the United Kingdom public sector. Supply Chain Manag. Int. J. 2009, 14, 128-137. [CrossRef]

45. De Haan, G. The BLK '21' programme in Germany: A 'Gestaltungskompetenz' based model for Education for Sustainable Development. Environ. Educ. Res. 2006, 12, 19-32. [CrossRef]

46. Kveiborg, O.; Fosgerau, M. Decomposing the decoupling of Danish road freight traffic growth and economic growth. Transp. Policy 2007, 14, 39-48. [CrossRef]

47. Parry, I.W.H.; Small, K.A. Does Britain or the United States Have the Right Gasoline Tax? Am. Econ. Rev. 2005, 95, 1276-1289. [CrossRef]

48. Wustenhagen, R.; Bilharz, M. Green energy market development in Germany: Effective public policy and emerging customer demand. Energy Policy 2006, 34, 1681-1696. [CrossRef]

49. Aslani, A.; Helo, P.; Naaranoja, M. Role of renewable energy policies in energy dependency in Finland: System dynamics approach. Appl. Energy 2014, 113, 758-765. [CrossRef]

50. Schandl, H.; Hatfield-Dodds, S.; Wiedmann, T.; Geschke, A.; Cai, Y.; West, J.; Newth, D.; Baynes, T.; Lenzen, M.; Owen, A. Decoupling global environmental pressure and economic growth: Scenarios for energy use, materials use and carbon emissions. J. Clean. Prod. 2016, 132, 45-56. [CrossRef]

51. Okano-Heijmans, M. Japan's 'green'economic diplomacy: Environmental and energy technology and foreign relations. Pac. Rev. 2012, 25, 339-364. [CrossRef]

52. Shouchuan, A.-Z. Greening and decarbonizing: Japan's development assistance. East Asia 2000, 18, 75-96. [CrossRef]

53. Panzner, G.W. Clean Technology Research in Germany: Examples of Implemented Projects. In Cleaner Production; Springer Science and Business Media LLC: Berlin, Germany, 1995; pp. 81-98.

54. Ryan, S.; A Throgmorton, J. Sustainable transportation and land development on the periphery: A case study of Freiburg, Germany and Chula Vista, California. Transp. Res. Part D Transp. Environ. 2003, 8, 37-52. [CrossRef]

55. Bhatia, M.; Jain, A. Green marketing: A study of consumer perception and preferences in India. Electron. Green J. 2013, 1, 1-20.

56. Karekezi, S.; Kithyoma, W. Renewable energy strategies for rural Africa: Is a PV-led renewable energy strategy the right approach for providing modern energy to the rural poor of sub-Saharan Africa? Energy Policy 2002, 30, 1071-1086. [CrossRef]

57. Fan, C.C. China's eleventh five-year plan (2006-2010): From "getting rich first" to "common prosperity". Eurasian Geogr. Econ. 2006, 47, 708-723. [CrossRef]

58. Martínez, C.I.P. Energy and sustainable development in cities: A case study of Bogotá. Energy 2015, 92, 612-621. [CrossRef]

59. Hobson, K. 'Weak' or 'Strong' Sustainable Consumption? Efficiency, Degrowth, and the 10 Year Framework of Programmes. Environ. Plan. C Gov. Policy 2013, 31, 1082-1098. [CrossRef]

60. Ward, J.D.; Sutton, P.C.; Werner, A.D.; Costanza, R.; Mohr, S.H.; Simmons, C.T. Is decoupling GDP growth from environmental impact possible? PLoS ONE 2016, 11, 1-14. [CrossRef]

61. Ellen MacArthur Foundation Towards a Circular Economy: Business Rationale for an Accelerated Transition; Ellen MacArthur Foundation Publishing: Cowes, UK, 2015.

62. Elkington, J. Cannibals with Forks: The Triple Bottom Line of 21st Century Business; New Society Publishers: Stony Creek, CT, USA, 1997. 
63. Richmond, B.; Peterson, S. An Introduction to Systems Thinking; High Performance Systems, Inc.: Lebanon, NH, USA, 2001; ISBN 0-9704921-1-1.

64. Frynas, J.G.; Wood, G.; Hinks, T. The resource curse without natural resources: Expectations of resource booms and their impact. Afr. Aff. 2017, 116, 233-260. [CrossRef]

65. Sachs, J.D.; Warner, A.M. The curse of natural resources. Eur. Econ. Rev. 2001, 45, 827-838. [CrossRef]

66. Pubule, J.; Blumberga, A.; Romagnoli, F.; Blumberga, D. Finding an optimal solution for biowaste management in the Baltic States. J. Clean. Prod. 2015, 88, 214-223. [CrossRef]

67. Folke, C.; Carpenter, S.; Elmqvist, T.; Gunderson, L.; Holling, C.S.; Walker, B. Resilience and sustainable development: Building adaptive capacity in a world of transformations. Ambio 2002, 31, 437-441. [CrossRef]

68. Dyllick, T.; Muff, K. Clarifying the meaning of sustainable business: Introducing a typology from business-as-usual to true business sustainability. Organ. Environ. 2016, 29, 156-174. [CrossRef]

69. Stahel, W.R. Sustainability and the Performance Economy. In The Performance Economy; Springer: Basel, Switzerland, 2010; pp. 269-287.

70. Kirchherr, J.; Reike, D.; Hekkert, M. Conceptualizing the circular economy: An analysis of 114 definitions. Resour. Conserv. Recycl. 2017, 127, 221-232. [CrossRef]

71. Hawken, P.; Lovins, A.; Lovins, L.H. Natural Capitalism Little; Brown and Company: New York, NY, USA, 1999.

72. Ellen MacArthur Foundation Towards the Circular Economy, Economic and Business Rationale for an Accelerated Transition; Ellen MacArthur Foundation Publishing: Cowes, UK, 2013.

73. Merli, R.; Preziosi, M.; Acampora, A. How do scholars approach the circular economy? A systematic literature review. J. Clean. Prod. 2018, 178, 703-722. [CrossRef]

74. McDonough, W.; Braungart, M. Remaking the Way we Make Things: Cradle to Cradle; North Point Press: New York, NY, USA, 2002; p. 104. ISBN 1224942886.

75. Rabl, A.; Spadaro, J.V.; Zoughaib, A. Environmental impacts and costs of solid waste: A comparison of landfill and incineration. Waste Manag. Res. 2008, 26, 147-162. [CrossRef] [PubMed]

76. Gu, F.; Hall, P.; Miles, N.J. Performance evaluation for composites based on recycled polypropylene using principal component analysis and cluster analysis. J. Clean. Prod. 2016, 115, 343-353. [CrossRef]

77. Pauli, G.A. The Blue Economy: 10 Years, 100 Innovations, 100 Million Jobs; Paradigm Publications: Boulder, CO, USA, 2010; ISBN 0-912111-90-9.

78. Iniguez-Montiel, A.J.; Kurosaki, T. Growth, inequality and poverty dynamics in Mexico. Lat. Am. Econ. Rev. 2018, 27, 12. [CrossRef]

79. Sachs, J.D. The Age of Sustainable Development; Columbia University Press: New York, NY, USA, 2015.

80. Rizos, V.; Behrens, A.; Van Der Gaast, W.; Hofman, E.; Ioannou, A.; Kafyeke, T.; Flamos, A.; Rinaldi, R.; Papadelis, S.; Hirschnitz-Garbers, M.; et al. Implementation of Circular Economy Business Models by Small and Medium-Sized Enterprises (SMEs): Barriers and Enablers. Sustainability 2016, 8, 1212. [CrossRef]

81. CEPAL Segundo Informe Anual Sobre el Progreso y los Desafíos Regionales de la Agenda 2030 Para el Desarrollo Sostenible en América Latina y el Caribe. Available online: https://repositorio.cepal.org/bitstream/ handle/11362/43415/S1800380_es.pdf (accessed on 20 September 2019).

82. World Bank World Bank National Accounts Data, and OECD National Accounts Data Files. GDP (Current US\$). Available online: https://data.worldbank.org/indicator/NY.GDP.MKTP.CD?name_desc=true (accessed on 9 October 2019).

83. CEPAL La Economía Del Cambio Climático en América Latina y el Caribe: Paradojas y Desafíos del Desarrollo Sostenible. Available online: https:/www.cepal.org/es/publicaciones/37310-la-economia-cambioclimatico-america-latina-caribe-paradojas-desafios-desarrollo (accessed on 14 October 2019).

84. Vergara, W.; Rios, A.R.; Paliza, L.M.G.; Gutman, P.; Isbell, P.; Suding, P.H.; Samaniego, J. The Climate and Development Challenge for Latin America and the Caribbean: Options for Climate-Resilient, Low-Carbon Development; Inter-American Development Bank: Washington, DC, USA, 2013; ISBN 1-59782-165-9.

85. Fernandes, E.C.; Soliman, A.; Confalonieri, R.; Donatelli, M.; Tubiello, F. Climate Change and Agriculture in Latin America, 2020-2050: Projected Impacts and Response to Adaptation Strategies; World Bank: Washington, DC, USA, 2012.

86. CEPALSTAT Distribución Porcentual de la Población en Áreas Urbana y Rural, Por Sexo. Available online: http://interwp.cepal.org/sisgen/ConsultaIntegrada.asp?IdAplicacion=1\&idTema=1\&idIndicador=33\&idioma= e (accessed on 23 October 2019). 
87. Janssen, R.; Rutz, D.D. Sustainability of biofuels in Latin America: Risks and opportunities. Energy Policy 2011, 39, 5717-5725. [CrossRef]

88. Eakin, H.C.; Wehbe, M.B. Linking local vulnerability to system sustainability in a resilience framework: Two cases from Latin America. Clim. Chang. 2009, 93, 355-377. [CrossRef]

89. Senge, P.; Hamilton, H.; Kania, J. The dawn of system leadership. Stanf. Soc. Innov. Rev. 2015, 13, 27-33.

90. North, D.C. Institutions, Institutional Change and Economic Performance; Cambridge University Press (CUP): Cambridge, UK, 1990.

91. North, D.C. Structure and Change in Economic History; Norton: New York, NY, USA; London, UK, 1981; ISBN 0-393-01478-9.

92. Wernick, D.A.; Haar, J.; Singh, S. Do governing institutions affect foreign direct investment inflows? New evidence from emerging economies. Int. J. Econ. Bus. Res. 2009, 1, 317. [CrossRef]

93. Chiu, H.-M. The Dark Side of Silicon Island: High-Tech Pollution and the Environmental Movement in Taiwan. Cap. Nat. Soc. 2011, 22, 40-57. [CrossRef]

94. Pellow, D.N.; Park, L.S.-H. The Silicon Valley of Dreams: Environmental Injustice, Immigrant Workers, and the High-Tech Global Economy; NYU Press: New York, NY, USA, 2002; ISBN 0-8147-6817-2.

(C) 2020 by the authors. Licensee MDPI, Basel, Switzerland. This article is an open access article distributed under the terms and conditions of the Creative Commons Attribution (CC BY) license (http://creativecommons.org/licenses/by/4.0/). 